Combined aprotinin and erythropoietin use for blood conservation: results with Jehovah's Witnesses. Ann Thorac Surg. 1994;58:1397403.

23. Hayashi J, Shinonaga M, Nakazawa S, Miyamura H, Eguchi S, Shinada S. Does recombinant human erythropoietin accelerate erythropoiesis for predonation before cardiac surgery? Jpn Circ J. 1993;57:475-9.

24. Konishi T, Ohbayashi T, Kaneko T, Ohki T, Saitou Y, Yamato Y. Preoperative use of erythropoietin for cardiovascular operations in anemia. Ann Thorac Surg. 1993;56:101-3.

25. D'Ambra MN, Gray RJ, Hillman R, et al. Effect of recombinant human erythropoietin on transfusion risk in coronary bypass patients. Ann Thorac Surg. 1997;64:1686-93.
26. Watanabe Y, Fuse K, Konishi T, et al. Autologous blood transfusion with recombinant human erythropoietin in heart operations. Ann Thorac Surg. 1991;51:767-72.

27. Kiyama H, Ohshima N, Imazeki T, Yamada T. Autologous blood donation with recombinant human erythropoietin in anemic patients. Ann Thorac Surg. 1999;68:1652-6.

28. Neumayer HH, Brockmoller J, Fritschka E, Roots I, Scigalla P, Wattenberg M. Pharmacokinetics of recombinant human erythropoietin after sc. administration and in long term i.v. treatment in patients on maintenance haemodialysis. Contrib Nephrol. 1989;76:131-42.

29. Flaharty KK. Pharmacokinetics and erythropoietic response to human recombinant erythropoietin in healthy men. Clin Pharmacol Ther. 1990;47:557-63.

\title{
JTCVS On-Line Manuscript Submission and Review
}

\section{Please visit http://www.editorialmanager.com/jtcvs/}

Effective September 15, 2001, authors and reviewers may submit manuscripts and reviews electronically via Editorial Manager, our new Web-based system with full electronic submission, review, and status update capabilities.

As we move from paper to electronic submissions, the Editorial Office will make proxy submissions of all manuscripts accompanied by a diskette containing the electronic files of the text, tables, and figures. Editors, authors, and reviewers will receive automatic e-mails when significant events occur.

We strongly encourage all authors and reviewers to use Editorial Manager. Although we will continue to accommodate the submission of paper manuscripts for some months, our goal is to be completely electronic within 9 to 12 months.

All individuals currently in our database for whom we have e-mail addresses will receive via e-mail a system-assigned username and password that can be used to log in to the system without prior registration. All those not receiving the e-mail must register the first time they use the system.

As with any broad systemic change, the conversion to the new system will take some time to complete. We ask your patience as we replace our in-office database with the new system. We also encourage you to take advantage of the speed and efficiency that the new system will provide for us all: editor, author, reviewer, and publisher. 